\title{
A Luta Contra a Desesperança: a Experiência de Gestantes com Hiv
}

\author{
Matos, Ana Paula Keller de; Oliveira, Fernanda Ferreira D.; Wernet, Monika \\ Universidade Federal de São Carlos — anakeller@gmail.com
}

Introdução: a descoberta do vírus da imunodeficiência humana (HIV) durante a gestação conduz a mulher a vivenciar o preconceito, a discriminação, a possibilidade de infectar o filho, promovendo com isso uma ponderação existencial. Nesse contexto, vivência uma assistência obstétrica que, nem sempre, associa-se aos preceitos de humanização. o atendimento aos portadores do HIV ainda está imerso em julgamentos e condutas que não ultrapassam os limites da teoria. uma assistência humanizada envolve o atendimento com respeito da individualidade e promoção dos direitos humanos dessas mulheres que vivem uma situação de sofrimento intenso. Nesse sentido, a vivência destas remete à experiência da esperança. a esperança é um processo multidimensional e dinâmico, focado na possibilidade de se alcançar o que é desejado. Incorpora o alicerce e a força para existir, sendo acionada nos momentos de dificuldades. Dessa forma, o convívio com o HIV durante a gestação conecta-se à experiência da esperança, por isso o presente estudo elencou a esperança como seu componente. Objetivo: Explorar e descrever experiências de esperança durante a gestação na mulher que descobre sua soropositividade para o HIV no pré-natal. Métodos: Este estudo selecionou, como referencial teórico, o Interacionismo Simbólico e teve a pesquisa de narrativas como referencial metodológico. a estratégia de coleta de dados adotada foi a entrevista semiestruturada associada ao genograma e ecomapa de esperança. Integraram o estudo sete mulheres gestantes que descobriram sua soropositividade para o HIV no pré-natal. Resultados: Estão apresentados e organizados a partir das seguintes unidades temáticas: "revisão da vida"; "ser mãe", "cuidar de si", "entrega à intervenção divina", "interações sociais e esperança". o fenômeno central identificado foi "A luta contra a desesperança". Conclusão: a tendência à desesperança faz-se fortemente presente no cotidiano gestacional dessas mulheres e existem interações que são promotoras da esperança e outras restritoras. Dentes estas o atendimento humanizado é uma ferramenta que pode promover a esperança. a mulher procura valorizar aquelas relações promotoras de esperança para poder alcançar o que estabeleceu como meta para este período: contribuir com a soronegatividade do filho gestado.

Matos, Ana Paula Keller de; Oliveira, Fernanda Ferreira D.; Wernet, Monika. A Luta Contra a Desesperança: a Experiência de Gestantes com Hiv. In: Anais do Congresso Internacional de Humanidades \&

Humanização em Saúde [= Blucher Medical Proceedings, num.2, vol.1]. São Paulo: Editora Blucher, 2014. ISSN 2357-7282

DOI 10.5151/medpro-cihhs-10741 